\title{
Rethinking Environmental Bureaucracies in River Chiefs System (RCS) in China: A Critical Literature Study
}

\author{
Qidong Huang * and Jiajun Xu \\ Department of Sociology, School of Public Administration, Hohai University, Nanjing 211100, China; \\ xujiajun@hhu.edu.cn \\ * Correspondence: huangqidong@hhu.edu.cn
}

Received: 8 February 2019; Accepted: 14 March 2019; Published: 17 March 2019

check for updates

\begin{abstract}
Efforts to understand the political complexities of water governance must include critical hierarchical or bureaucratical perspectives. The River Chiefs System, China's national mechanism which has evolved from local attempts, values more political control than governance efficiency. Water governance, which is regarded as a political task, is allocated from river chiefs at higher levels to lower levels. The River Chiefs System stipulates that local river chiefs fully mobilize and integrate various technical and administrative forces to achieve environmental goals. However, the strengthening of local authority enables local river chiefs to combat or eliminate state power. Although public involvement in the River Chiefs System is encouraged to some extent, "government-dependent" public participation hardly ensures real public involvement and supervision.
\end{abstract}

Keywords: water resources management; environmental bureaucracies; decentralization; centralization; River Chiefs System

\section{Introduction}

Power distribution, hierarchical systems, and public involvement are three relatively independent but interconnected aspects which are usually discussed in depth in water governance research. Theories concerning water governance usually regard the three aspects as the keys to the success or failure of water governance [1,2]. Scale, as one of the determining factors behind many environmental problems, has often been defined as the spatial, temporal, quantitative, or analytical dimensions used to measure and study environmental phenomena [3]. There does exist a physically predetermined scale: the basin or watershed. Meanwhile, scale is also socially and politically composed (even collided), and the simultaneous construction, in turn, affects governance practices [4]. We claim that, up to now, there were two main theoretical findings concerning power distribution across scales: (1) Scale is both geographically and socially constructed, and (2) scale is both fixed and fluid $[1,5,6]$. The complicacy of power distribution across scales might be sufficiently demonstrated by large-scale water management (like trans-basin or transnational water management). The EU Water Framework Directive (WFD), as one of the most ambitious attempts across Europe to institutionalize power distribution in water governance, has demanded all 27-member states to comply with and to implement relevant regulatory norms simultaneously, unconditionally, and in full in accordance with a strict timetable. Developing a unified governance model for Europe as a whole is only one aspect of this ambitious plan. Other aspects include setting objectives for water quality, pricing water to reflect environmental externalities, encouraging public involvement, and taking a joint and coordinated action to pollution control. However, the reasonable allocation and coordination of governance authority among Europe, member 
states, river basin management agencies, and stakeholders will affect the achievement of overall governance objectives [7].

Many studies have attributed the difficulties in water policy implementation to a failure of communication and adaptiveness of government agencies at different levels of their hierarchy [8]. This view has been further confirmed by researches demonstrating the importance of improving the flexibility of the "rigid" structure of water management agencies $[9,10]$. Water fluidity and the increasingly complex water environment require that the mechanism construction become more adaptable to complicated environmental, social, and political situations. In this transition, different levels of institutions may achieve different degrees of transformation, perhaps more intense at higher levels, or vice versa. The degree of transition may affect the operational efficiency of the overall mechanism: a system that has undergone deep-seated and wide-ranging changes may face the danger of losing its traditional advantages, while an overconservative system may not be able to face the ever-changing environmental challenges at all $[9,10]$. However, the change of the hierarchical structure alone is not enough to improve the operation of environmental institutions. The distribution of power among different agencies, the degree of specialization of different departments, and the specific political culture may also affect the implementation and implementation of policies [11].

A growing consensus among researchers is that both power and hierarchical institutions operate more efficiently and steadily with an open and pluralistic social structure which ensures more active and effective participation by civil society, academics, private enterprises, and medias [2,12]. Public participation is supposed to contribute to environmental governance by reducing or eliminating institutional bias or power imbalance. The effectiveness of public participation depends, to a large extent, on the key principles summarized by some scholars, which includes early participation in water governance process (helping sort out major issues), interactive consultation (ensuring that opinions are fully discussed among different stakeholders), the institutionalization of participation processes (promoting normalization and standardization of public participation), and feedback mechanisms (helping the public understand the governance process and improve their ability to participate). The performance of some water-related projects may also be improved by promoting the participation of project users. Evidence from laboratory and framed field experiments in China, India, and Vietnam has demonstrated that promoting the participation of irrigation users in designing the rules for water distribution and water use monitoring and sanctioning improve the performance of irrigation systems [13].

China has gradually promoted the River Chiefs System (RCS) throughout the country since 2008. The mechanism stipulates that the Party and government leaders at all levels in China act as "river leaders" in their respective administrative regions, responsible for the management and protection of the corresponding parts of rivers and lakes. The main tasks of the chiefs include water resources protection, shoreline management, water pollution prevention and control, water environment management, water ecological restoration, and law enforcement. RCS, as a new system vigorously implemented by the central government, has aroused different views in academic circles. In order to evaluate the system, which may have a significant impact on China's environmental governance, we analyze it from its power, bureaucracy, and public participation. We also compare it with water governance in other countries or regions in order to form a more complete picture. Particularly, we explore how the scales of power are reshuffled within institutional arrangements, what effects have reinvented environmental hierarchy produced on water governance, and to what extent public involvement is encouraged in RCS. We take the article as an independent reflection of the ten years' development of RCS. We find that (1) RCS is essentially a "head responsibility system" which emphasizes the centralized and maximum use of the power of the heads in specific jurisdictions; (2) river chiefs may seek opportunities for power expansion in their respective jurisdictions when the central government changes or adjusts the existing environmental policies according to the political and economic needs of the country, which often leads to the instability of environmental relationships between the central and the local governments; and (3) as a relatively closed water environment 
management system, RCS was established mainly to strengthen the government's water management rather than to create a platform for diversified governance.

The remainder of the article is organized as follows. Section 2 describes our research methods, and Section 3 presents the results on the evolution of RCS and the political structure in which RCS operates. After providing our interpretations of the results in Section 4, we conclude with findings on the adaptative development of RCS in the final section.

\section{Methods}

We adopted a literature review as the main method in our study of RCS. The literature included domestic and foreign studies both on water management or RCS in China and on river basin management outside China. In addition to the literature review, we held several discussions with relevant scholars and government officials. What we discussed involved the key tasks of water environmental governance, watershed coordination, administrative law enforcement, environmental governance assessment, and third-party assessment indicators and mechanisms.

We were invited to participate in writing a book on China's RCS. We, thus, had the opportunity to discuss RCS problems with fifteen other coauthors of the book, who were from different research institutes across the country, when we discussed the writing of the book. We also had the chance to meet some government officials and corporate representatives of environmental governance companies since they were also invited to attend the meetings.

As we were often entrusted to train civil servants about RCS in some provinces such as Anhui, Jiangsu, and Zhejiang, we had the opportunity to talk with them about the operation of RCS. After we had the training courses, we were often invited to visit rivers there that implemented RCS. We cogitated the operation of RCS through observation, comparison, and discussion.

\section{Results}

\subsection{Evolution of RCS: From Local Trials to a National Mechanism}

In April 2007, a large-scale cyanobacteria incident occurred in Taihu Lake in Jiangsu Province. Wuxi, a city beside Taihu, was seriously affected by the crisis with a serious shortage of drinking water and damage to fishery resources. After experiencing this crisis, the Wuxi municipal government decided to resume the long-term governance mechanism of water environment by issuing an official document: "Controlling Objectives and Assessment Methods of Water Quality of Rivers (Lakes, Reservoirs or Springs) in Wuxi". The document stipulated that the mayor of Wuxi assumed the office of the general river chief of a total of 64 rivers in the jurisdiction, and the governors of the districts (or counties) were appointed the river chiefs within their respective jurisdictions. River chiefs at each level now bore full administrative responsibility for the protection of water resources, the management of water areas and shorelines, and the prevention and control of water pollution within their jurisdictions $[14,15]$. Jiangsu Province decided to launch RCS in the whole province in 2008, and 5 years later, RCS covered almost all the rivers in the province.

In December 2016, the State Council issued an official document called "Comprehensive Implementation of River Chiefs System", which marked the rise of RCS from a local emergency policy to a national will. Two key points were set in the document: first, a system of river chiefs at the provincial, municipal, county, and township levels should have been established throughout the whole country, and all posts of river chiefs were to be held by the heads of the respective jurisdictions. Second, river chiefs were responsible for water resources protection, water pollution control, water ecological restoration, and shoreline management within their respective jurisdictions. By the end of June 2018, RCS had been implemented in all 31 provinces and autonomous regions in China, with approximately 300,000 leaders who assumed the office of river chiefs at the provincial, municipal, county, and township levels. Some provinces even extended the system to the village level, and there were approximately 760 thousand river chiefs at the village level in these provinces [16]. 


\subsection{The Logic of RCS: The Reproduction of China's Hierarchical System in Environmental Governance}

China is a politically centralized country with five levels of governments, namely the central, provincial, city, county, and township. The central government plays a leading role in the division of administrative power among the governments at various levels, and the power is decomposed from the higher to lower levels [17]. RCS duplicates the basic logic of intergovernmental power distribution: river chiefs at high levels are responsible for managing and monitoring chiefs at the lower levels, and the chiefs at lower levels shall report regularly to their counterparts at higher levels on the management of rivers or lakes within their jurisdictions. RCS is a framework in which the river chiefs at high levels just set the ultimate goals of water governance (such as water quality, shoreline management, and ecological restoration, etc.) instead of making detailed management plans for river chiefs at lower levels $[18,19]$. How much authority the chiefs at lower levels owns depends entirely on their superiors, although they always have a certain political power to formulate and implement specific policies according to local resources endowment [20,21].

\section{Discussion}

\subsection{Reshuffled Power: Is It Decentralized or Centralized?}

\subsubsection{Responsibility Mechanism of RCS}

RCS sets the government leaders as river chiefs at several levels, making them the first responsible persons for the water environment within their respective geographical jurisdiction. River chiefs are responsible for the drinking water safety, water source dispatching, water saving management, and sewage treatment, which were once subordinate to the respective authorities of environment, agriculture, resources, and transportation [19]. The responsibility mechanism ensures river chiefs a full range of power in water governance to facilitate an effective cooperation among different government divisions concerned. Ten provinces in the Yellow River Basin even set up a joint meeting mechanism of provincial RCS offices in May 2017. The joint meetings coordinate affairs involving upstream, middle stream, or downstream left and right banks and conflicts cross provincial borders. The meetings include general and professional joint meetings: the former discusses major or principal issues while the latter deals with specific issues such as water resources protection, coastline management, water pollution prevention and control, water ecological restoration, etc. (www.yellowriver.gov.cn/xwzx/ hhyw /201705/t20170524_176492.html, available on 24 September 2018.).

However, some researchers criticize that the system actually follows a typical pattern of "ruling by men" instead of by legal systems. Wang (2009) claims that river chiefs' power influence, environmental awareness, educational background, personal authority, and governance experience affect the efficiency and effects of RCS [22]. Liu, He, and Zhou (2016) claim that, in particular, RCS is a system with obvious characteristics of power as it emphasizes the maximum use of the power of a river chief in a specific administrative system [23]. Li (2009); Habich-Sobiegalla (2018); and Wan, Chen, and Sperling (2018) maintain that a paternalistic system is far from the rationalism and rule of law which are advocated by the modern bureaucracy [24-26]. Xia (2017) further maintains that the mechanism, operating in a characteristically patriarchal style, is far from the rational and legal spirits advocated by the modern bureaucracy and may hinder the sustainable development of resources and the environment, although it may have short-term environmental effects [6]. Some river chiefs, in order to pursue the short-term effects of environmental governance, implement a river course construction and transform the river landscape to the greatest extent during their terms of office by forcefully decomposing the indicators of the water environment into various governments units. RCS, an attempt to integrate water management, actually made it more disconnected.

Obviously, RCS has a deepened power inequality to some extent. This situation also exists in many other developing countries. Since the democratic reform of the 1980s, Brazil has developed a model of water resources reform based on the decentralization of power. Water basin committees in Brazil 
are transformed into tripartite structures, with an equal representation of state, municipal, and civil society actors. However, the long-term state control of power makes it difficult for new participants to substantively participate in policy formulation and implementation. Despite the gradual transition in water governance, the inequality of power has not been fundamentally alleviated $[27,28]$. Since the 1990s, the South African government developed a framework of water management which adopted ideas of collaborative governance and aimed to change the uneven distribution of power. However, the power asymmetries of relevant actors still hindered the effective operation of the framework [29].

In addition, the expedient implementation of lower river chiefs is a matter worthy of attention, although the strict RCS enables the lower river chiefs to make rapid responses to the decisions of the higher ones (the decisions of provincial river chiefs are undoubtedly derived from the environmental policies of central governments): The local power obviously has enough opportunities to combat and dismantle that of the state [30]. Some uncertainties are injected into the hierarchical information flow which deepens the degree of information asymmetry between the upper and lower levels of river chiefs. Although the central government strengthens the monitoring of local chiefs (such as vertical fund management), local chiefs and local enterprises often form communities of interest against the central government [19]. Another contributing factor of expedient execution is the separation of the policy design of the superior and the policy implementation of the subordinate, which usually leads to the non-continuity and incompleteness of policy implementation [31,32]. Local river chiefs often adopt informal administrative forms such as the employment of some informal personnel to participate in water management. They might resort to scapegoating once there occurs some administrative flaws in water governance [33].

\subsubsection{Assessment and Accountability Mechanism of RCS}

Decentralization reforms usually mean an increase in local government responsibility. RCS is setting the water quality and river course management as one of the important assessment contents of local leaders. Pia (2017) claims that an accountability review process offers a ray of sunshine and a turning point toward a greater accountability in the government [34]. Under the accountability mechanism, the sense of service of river chiefs and the administrative efficiency of local pollution control have been improved to some extent [35].

However, the feasibility and effects of the accountability of RSC are still questioned by some researchers. First, with the assessment criteria being usually set by the government instead of by independent third parties, some key standards might be tailor-made for chiefs instead of for the improvement of water governance [33]. Second, the impartiality of an accountability review process might not be guaranteed since environmental bureaus or RCS offices, which are usually responsible for the implementation of the process, are lower than the river chiefs in administrative levels [36]. It is worth mentioning that some cities, such as Suqian of Jiangsu Province, introduced independent third-party evaluation systems since July 2018.

As an important part of the whole accountability system, the one-vote-down mechanism makes river chiefs bear the administrative responsibility for water governance under their jurisdiction. This means that various indicators of water governance will affect the river chiefs' promotion. Although the mechanism might force river chiefs to make maximum use of their power to improve environmental governance, river chiefs, due to various reasons (such as limited tenure, urgent tasks, etc.), might try to cater to environmental indicators and data rather than try to realize the sustainable environment. Some river chiefs even use their power to the maximum extent to avoid the punishment of the "one vote veto system", which breaks not only through the restrictions of the legal and administrative framework but also through that of moral norms.

\subsubsection{The Lowest Appropriate Level}

Decentralization is a process in which the power is gradually devoluted to local-level institutions which are downwardly accountable to their jurisdictions. Water resources management in most 
countries has traditionally been the task of government entities, especially that at relatively higher government levels (such as federal or central levels). However, this mode often failed to produce desired results. Many analyses, based on the hypothesis that the decentralization of power and the participation of stakeholders are conducive to achieving a more reasonable and effective solution, indicate that good water governance requires the effective decomposition of decision-making power and the active involvement of stakeholder groups [37-39]. The term "lowest appropriate level" implies not a recipe for a full decentralization at all costs but a delegation of locally adapted decision-making power to the appropriate level for optimal results [40], with some decisions being made by local or regional stakeholders (local governments, entrepreneurs, farmers, fishermen, etc.) while others being still under the control of the state or provincial levels. In other words, decentralization does not have an ideal fixed level. It may be negotiated and distributed among stakeholders at different levels according to resource endowments, policy implementation, and local conventions to keep approaching the "best appropriateness".

Some researchers claim that RSC has responded positively to this trend of decentralization and demonstrates its important role in the equal utilization and effective management of water resources $[16,24,41]$. Although these researchers are optimistic that the central power has shifted to the local levels and such a shift may have produced beneficial results, the findings of some other studies are generally negative. They claim that the central government delegates its power mainly to the provincial level while the agencies at the county or township levels are not granted significant or major regulatory authority [33]. These so-called "beneficial results" are not sustainable because they might be the results of compromise or exchange of power among the government agencies at various levels [20].

Some studies suggest that the decentralization of power from the provincial levels to the county level or lower may improve the current water governance because local governments with an appropriate expanded power might be more responsive to changes in the water environment, while other scholars warn that, under the former centralized system, the rapid decentralization of power and lack of supporting systems might lead to power misuse or corruption [41,42]. An important implication in their research is that there is no perfect prescription for a full decentralization at all costs, but locally adapted decentralization of power, with some power being decentralized to local levels while other being retained at central or provincial levels, might produce some desirable consequences.

The decentralization of water resource management, the process by which a federal or central government transfer its powers to authorities or actors at appropriate levels in a political-administrative hierarchy, has been a major global trend in water governance for the past decades [43]. The successful water reforms in Mexico or other Latin American countries were partly attributed to the appropriate decentralization of power, which allowed for a more efficient and extensive provision of services by actors or agencies in specific sectors or regions [44].

\subsection{Reinventing the Environmental Hierarchy: Is It Getting Softened or Rigidified?}

\subsubsection{Political Bureaucracy at Higher Levels}

An ideal bureaucracy is to ensure its accurate, rapid, and stable operation through the principles of power division and technicalization. The principle of power division means that each unit of the government perform its own duties without interfering the terms of reference of other units, while that of specialization indicates that different units undertake their professional and technical tasks with corresponding professional ethics and technical standards [36,45]. However, China's current hierarchical system, of which the operation does not fully conform to the classical definition of hierarchy, is actually a political bureaucracy with a divergence between its structure and function [8]. The system, which pursues political control over administrative efficiency, seems to be a political mobilization system that deviates from the principles of power division and technicalization that modern hierarchical structures should have. The river chiefs' decisions and actions are largely influenced by orders from their superiors, rather than by the demands of water governance [41]. 
When it comes to environmental governance, the power system usually follows a simple process of environmental deterioration, river chiefs' consultation, formulation of plans, implementation of plans, and evaluation of the implementation, which involves too much political mobilization [30].

In the face of significant changes in resources and the environment, higher-level governments (especially provincial or interprovincial coalitions) are likely to respond by expanding the scope of power, establishing provisional institutions, adopting mandatory regulatory tools or exercise-based governance, or launching a campaign-style governance. In order to cope with the worsening rural water pollution, the state council demands in its "Strategic Planning for Rural Revitalization (2018-2022)" that the four-level RSC be extended downward to a five-level one, with village chiefs being appointed as river chiefs. This implies that village heads, usually elected by villagers, have somehow entered the orbit of national power mobilization [16]. All the river chiefs running on the track must carry out certain political tasks of environmental governance within a specified period of time, ignoring the elements of citizen participation, expert discussion, and policy legalization in the process of environmental governance [18].

\subsection{2. "Soft" Bureaucracy at Lower Levels}

A contracting system of environmental governance is implemented downwards through the levels of administrative hierarchy under the convention of political mobilization in China. Environmental governance is borne by subordinate river chiefs as political tasks. Subordinate river chiefs, both as "subcontractors" and administrative chiefs of their jurisdictions, usually fully mobilize and integrate various technical and administrative forces to achieve environmental goals [46,47]. Local river chiefs improve the efficiency and pertinence by reorganizing government agencies, training technicians, and establishing communication mechanism. Various stakeholders then might effectively participate in local water governance with the encouragement of local river chiefs [41].

Although China's political system is highly centralized at higher levels, the contracting system of environmental governance promotes power negotiation and local environmental autonomy at lower levels. The increasing pressure of water governance and administrative assessment facilitates lower river chiefs' negotiations with their superiors. This has led to an interesting situation: A power distribution mechanism similar to that of a federal state is operating in a centralized country [41]. Although the central or provincial governments still grasp some important policies or financial resources, local river chiefs can still bargain and contend with their superiors as they bear the primary responsibility for water governance in their jurisdiction [48]. Instead of passively accepting political tasks of water governance, local river chiefs usually strive to gain more power to facilitate their water governance in their jurisdiction. Their initiatives in soil erosion control, water ecological function restoration, management information system, etc. are usually recognized by the central or provincial governments.

The local environmental autonomy under a centralized political system embodies the main characteristics of "soft hierarchy": With political decisions being more centralized, jobs and responsibilities have become more decentralized. While dealing with specific environmental issues, local river chiefs can even "jump" scales to obtain a full range of policy support, showing the characteristics of "softness". Although the central or provincial governments have made specifications on funding schemes for basin governance, the local governments usually have some operational space to make appropriate adjustments to these funding plans. If appropriate institutions are set up to coordinate this flexibility, governance policies can be more easily implemented in specific areas and sectors. Moss (2012) argued that the future organizational structure in the EU does not necessarily coincide with the geographical scope or administrative divisions of river basins. The member states might set "appropriate competent authority" in their own national or regional context to ensure the flexibility of power flow at appropriate levels. This special fit of power and organizations would lead to the diversification of governance models. Sweden and Portugal established new authorities to fit their river basin management, with the level of governance shifted from jurisdictions 
to hydrographic regions [49,50]. Participatory structures of different sizes and forms in France were frequently introduced at the hydrological scale without fully adapting them to political structure [51]. After examining the case of Georgia, a transitional country, Withanachchi et al. (2018) found that granting a greater power to local governments can bring more financial, political, and social advantages to local water institutions regarding water quality issues since the local governments are the proximate level of water pollution control [52]. The degree of softness and the magnitude of scale jumping follow the specific logic of the division of powers among the governments at various levels. The division of power between the higher and lower governments not only refers to the principle of efficiency but also considers the political and social risk factors [53]. The higher governments, with the maximization of social welfare as their fundamental objective, ensures good environmental governance by setting corresponding tasks, formulating incentive mechanisms, and sharing power with lower governments. The higher governments will adjust their power division and incentive mechanism if the local government's governance behavior might cause political or social risks. Therefore, the governments at higher levels will tighten their power accordingly once the actions of lower river chiefs are believed to deviate from their policy orientation.

\subsection{Recontextualising Water Governance: Is Public Involvement Encouraged in RCS?}

\subsubsection{Government-Based Governance}

In general, political bureaucracies strive to achieve institutionalized operation through standardized procedures and accountability mechanisms. Particularly noteworthy is that the system usually regards "administrative achievement" instead of "environmental achievement" as the primary indicator of environmental governance. In order to effectively respond to environment deterioration, bureaucracies need to select "appropriate" policy tools [54-56]. Campaign-style governance has become the most popular policy tool in coping with major changes of the environment. It becomes very common for governments at all levels to establish temporary paramilitarized organizations (such as RCS Coordination Office, etc.) during the period of campaign-style governance. The emphasis of the unity and rapidity of action in campaign-style governance often leads to the neglect of the transparency and effectiveness of decision-making, which may lead to the absence of public participation, an important goal of modern environmental governance.

It must be admitted that the policy tools that China's government can choose in environmental governance are undoubtedly limited, lacking both contractual and cooperative governance tools (for example, voluntary tools and mixed tools in the candidate repository of policy tools are almost missing). Thus, the sole type of policy tool which the government may choose is the mandatory one when the government is in the face of major changes in the environment and the urgent need for a prompt response.

The practice of public participation in other countries and regions can provide a useful reference for water governance in China. The European Water Framework Directive (WFD) requires member states to involve all of the interested parties in the making and implementation of new water policies. As a concrete measure to implement the principle of social learning, social participation is regarded as an important way to promote water governance. After comparing the results of French and German case studies, Borowski et al. (2008) found that spatial misfits, which are difficult to fully exclude, can be well-avoided if social participation is encouraged. This is particularly suitable for larger basins (such as those that cover the entire country or even cross borders) which include more different stakeholders and need more public consultation and participation [51]. The establishment of some water user associations, as an ongoing political process, alleviated power asymmetries in the framework of collaborative water governance in South Africa as mentioned in Section 4.1.1 [29]. 


\subsubsection{RCS's Stance on Public Participation}

RCS, a relatively closed water management system, continues the Chinese government's tradition of relying on administrative coercion. River chiefs and the government they represent usually regard themselves as the sole legal subjects of water management. They often deliberately avoid or alienate the participation of citizens and social organizations in the following ways: (1) Setting a high threshold for public participation. Most local governments have not established effective platforms for public participation, and some even excluded public participation by complicating the participation rules and raising the threshold of participation. Environmental proposals or programs raised by the public must be subject to political review at local levels to ensure political correctness before they are submitted to government at higher levels. (2) Refusing to disclose important information to the public: The governments usually believe that the public may become an external force affecting the internal assessment of RCS if the public has full access to the key indicator of water quality. Wang (2015) and Tang (2017) suggest that data disclosure will definitely affect bureaucratic balance and, thus, face resistance from RCS [20,41].

What the government welcomes is the "government-dependent" public participation which are usually under the guidance of the government in terms of the ways and degrees of participation. It is, thus, difficult for the public to fully express their independent positions so as to achieve a real sense of effective supervision of government decision-making and policy implementation. River chiefs of Beijing invited the public to vote for the contest of Beautiful Rivers and Lakes of Beijing in 2017, but they stipulated that the public could only vote designated rivers within a specified time based on some specified index (like river floatage and vegetation maintenance). The public, unable to obtain other key data and parameters in real time, could only vote on their personal observations of the river environment. Moreover, the public had no idea about the sponsors and the selection process of the competition. (http:/ / zhengce.beijing.gov.cn/library/192/33/50/438650/1292740/index.html, available on 20 November 2018.).

It is rather difficult for the sole governance mechanism of RCS to meet the comprehensive requirements of water management, although the system initially sought the rationality, fairness, and efficiency of the use of power with an impersonal and professional spirit. An important direction of RCS reform is to embed the public participation mechanism in the authority monopoly and central control mechanism of RCS so that the new governance system can ensure the rights of individuals and groups to enter the public sphere as actors who are able to legitimately voice their demands. Wang (2009) suggests that river chiefs at various levels should set up regular channels for dialogues with the public and give timely feedback on the problems reflected [22]. Fu and $\mathrm{Li}$ (2009) proposes that representatives of communities, nongovernmental organizations, and third-party assessment institutions should be invited join the joint meetings of river chiefs [18].

The extent and scope of public involvement in RCS are rather limited. One reason is that public involvement is difficult to have a substantial impact on higher-level policy making. The public can only participate in river management at lower levels (In areas where rivers are relatively abundant, the lower river chiefs may even be at the village levels.). Low-level river chiefs report the problems raised by the public to their superiors and wait for the superiors' responses, which usually results in delays in disposal and, thus, affects the effectiveness of public participation. Even if the public can address inquiries to high-level river chiefs on related issues, they will find that the river chiefs questioned can transfer their pressure to their subordinates. Such an involvement at lower ends is not conducive to promoting environmental governance.

The other reason is that the RCS's use of internet technology actually excludes some people from water governance. RCS, a newly established system, attaches too much importance to participation based on modern internet technology (such as public opinion collection systems through applications on smart phones) rather than traditional methods (such as meetings, interviews, etc.). The internet is indeed offering an entirely new, much improved mechanism for the public to participate in water governance, but it also isolates people who do not use the Internet. Educated young people are 
more likely to participate in internet-based activities than the less educated along with females and seniors [24,57].

\section{Conclusions}

The three closely related factors of power, hierarchical structure, and public participation have a profound impact on environmental governance. On the one hand, the power distributes and flows among the hierarchical agencies at different levels, while the agencies implement environmental policies in the corresponding jurisdictions according to the size and scope of the power granted. On the other hand, public participation plays an important role in policy rectification, power supervision, and institutional operation in the implementation of environmental policies. The inappropriate matching of these three factors may lead to the failure of environmental governance.

Although calls for power decentralization have echoed around the world, inappropriate or mismatched power restructuring may have adverse consequences such as an opaque process of decision-making and incomplete policy implementation. Truly functioning decentralization schemes must consider avoiding these adversities. In addition to decentralizing power to the appropriate levels, how to achieve the maximum policy effect by coordinating the power at these levels should also be considered. It is like a doctor's diagnoses for patients: although the patients are diagnosed as having a particular illness or problem, the doctor prescribes different prescriptions based on each patient's specific situation [58].

On the whole, China is a country where the hierarchical system ensures that the central government at the top has the power not only to set environmental governance goals but also to choose ways to achieve them. This is different from Europe: Europe is a union in which central organisms (European Commission) provide a macroscopic guiding framework while its member states possess a high degree of legislative autonomy [59]. RCS, a reflection of China's bureaucracy system, is essentially a "head responsibility system" which emphasizes the centralized and maximum use of the power of the heads in specific jurisdictions. River chiefs, the highest power holders of administrative areas, mainly carry out water governance through the power within jurisdictions. Although they only have very limited power granted by the central government, each level of river chiefs has considerable administrative autonomy in their own jurisdictions, and this is why it is often called a system ruled "by man" or "by power". River chiefs at different levels may seek opportunities for power expansion in their respective jurisdictions when the central government changes or adjusts the existing environmental policies according to the political and economic needs of the country. This often leads to the instability of the environmental relationship between the central and the local governments and, thus, affects the effect of environmental governance.

Furthermore, the distribution of power at all levels is a process of "administrative decentralization" rather than of "social decentralization". This means that decentralization is carried out within the government sphere rather than between the government and society. As a relatively closed water environment management system, RCS was established mainly to strengthen the government's water management rather than to create a platform for diversified governance. Therefore, the operation, assessment, and accountability of RCS does not substantially encourage public participation. The closeness of the government water management system might not respond effectively to the diversified needs of social interests. River chiefs are arranged in a strict hierarchical system according to their levels of power, and the lower river chiefs are under the strict control and supervision of the higher ones. In order to pursue the effect of environmental governance in a specific period of time, river chiefs try to accomplish the political task of environmental governance within their term of office by decomposing the indicators of environmental governance into various governmental agencies, ignoring the technical process, public participation, expert discussion, and other elements that environmental governance should have. Thus, there always exists an extreme complexity and a large number of uncertainties in water governance: Fluctuations in the river water quality might occur during the process of water governance, the term of office of a river chief may not coincide with the 
period of water treatment, and the economic and social development of administrative jurisdictions through which the same river flows may be different. The complexity of water governance collides with the rigidity of environmental bureaucracies. An inevitable consequence of this is that environmental governance has to be operated within the rigid framework of a bureaucratic system and, thus, presents characteristics of a "bureaucratic environmental governance", which might become an obstacle to effective water governance.

Author Contributions: Q.H. designed the research and wrote the manuscript. J.X. collected the research materials and revised the manuscript.

Funding: This study was supported by grants from (1) "Research on Environmental Conflicts and Micro-governance Mechanism of Small Rural Watershed in China" sponsored by the Research Foundation on Humanities and Social Sciences of the Ministry of Education of China (Grant No. 19YJA840003); (2) "Research on the Cross-border Water Pollution in Jiangsu Province and Innovation of Cooperative Treatment" sponsored by Hohai University "Fundamental Research Foundation of Central Universities" (Free Exploration Project B) (Grant No. 2019B20514); and (3) "Research on the Construction of River Chiefs System and Innovation of Water Environment Management in Jiangsu Province" sponsored by Philosophy and Social Sciences Research Foundation of Department of Education of Jiangsu Province (Grant No. 2018SJA0026).

Acknowledgments: We are thankful for the valuable suggestions from Sarah Rogers at University of Melbourne as we prepared the article. We also appreciate the comments and help from three anonymous reviewers and the editors which are essential in the improvement of the article.

Conflicts of Interest: The authors declare no conflict of interest.

\section{References}

1. Huang, Q.; $\mathrm{Xu}$, J. Scales of power in water governance in China: Examples from the Yangtze River Basin. Soc. Nat. Resour. 2017, 30, 421-435. [CrossRef]

2. Huang, C.; Chen, T.; Yi, H.; Xu, X.; Chen, S.; Chen, W. Collaborative environmental governance, inter-agency cooperation and local water sustainability in China. Sustainability 2017, 9, 2305. [CrossRef]

3. Buizer, M.; Arts, B.; Kok, K. Governance, scale, and the environment: The importance of recognizing knowledge claims in transdisciplinary arenas. Ecol. Soc. 2011, 16, 21. [CrossRef]

4. Marston, S. The social construction of scale. Progress in Human. Geography 2000, 24, 219-242.

5. Hoogesteger, J.; Verzijl, A. Grassroots scalar politics: Insights from peasant water struggles in the Ecuadorian and Peruvian Andes. Geoforum 2015, 62, 13-23. [CrossRef]

6. Brenner, N. The limits to scale? Methodological reflections on scalar structuration. Prog. Hum. Geogr. 2001, 25, 591-614. [CrossRef]

7. Moss, T. Spatial fit, from panacea to practice: Implementing the EU Water Framework Directive. Ecol. Soc. 2012, 17, 2. [CrossRef]

8. Timmerman, J.G.; Interwies, E. Transboundary regimes and the role of information. Newater Policy Brief 2017, 5, 1-4. [CrossRef]

9. Berkes, F.; Colding, J.; Folke, C. (Eds.) Navigating Social-Ecological Systems: Building Resilience for Complexity and Change; Cambridge University Press: Cambridge, UK, 2003.

10. Folke, C.; Carpenter, S.; Walker, B.; Scheffer, M.; Chapin, T.; Rockström, J. Resilience thinking: Integrating resilience, adaptability and transformability. Ecol. Soc. 2010, 15, 20. [CrossRef]

11. Pahl-Wostl, C. Requirements for adaptive water management. In Adaptive and Integrated Water Management: Coping with Complexity and Uncertainty; Pahl-Wostl, C., Kabat, P., Moltgen, J., Eds.; Springer: Berlin/Heidelberg, Germany, 2007; pp. 1-22.

12. Estrella-Luna, N. Public participation and communicative interaction: The structural mechanisms of institutional bias. Environ. Justice 2000, 3, 135-140. [CrossRef]

13. Pham, L.; Otto, I.; Zikos, D. Self-governance and the effects of rules in irrigation systems: Evidence from laboratory and framed field experiments in China, India and Vietnam. Water Econ. Policy 2018, 5, 1850009. [CrossRef]

14. Zhu, W. Exploring Effectiveness of River Chiefs System in water environment. Jiangsu. Water Conserv. 2013, 10, 1-7. (In Chinese)

15. Huang, A. River Chiefs System: Institutional form and innovation trend. Xuehai 2015, 4, 141-147. (In Chinese) 
16. Ren, M. River Chiefs System: A sample study of cross-sectoral collaboration in a watershed in China. J. Beijing Inst. Adm. 2015, 3, 26-36. (In Chinese)

17. Zhang, L. Ecological dimension of modernization of national governance capacity. Adm. Forum 2015, 6, 15-19. (In Chinese)

18. Fu, S.; Li, W. River Chiefs System needs public supervision. Environ. Prot. 2009, 9, 22-23. (In Chinese)

19. Xia, B. The reform of River Governor Mechanism and practice of integrated water management. China Water Conserv. 2017, 2, 50-57.

20. Wang, Y. Paradox of River Chiefs System and its resolution. West. Law Rev. 2015, 3, 1-9. (In Chinese)

21. Ding, Y. Anti bureaucracy Governance: The Chinese experience of state governance. Academia 2016, 11, 23-30. (In Chinese)

22. Wang, Z. The Origin, Development and Evolution of Multicenter Governance Theory. J. Southeast Univ. (Philos. Soc. Sci. Ed.) 2009, 11, 30-38. (In Chinese)

23. Liu, F.; He, T.; Zhou, Y. An analysis of the legalization of the River Chiefs System in the context of governance modernization. Zhejiang Acad. J. 2016, 6, 20-30. (In Chinese)

24. Li, Y. Rethinking River Chiefs System from the perspective of water pollution control. Environ. Prot. 2009, 9, 15-25. (In Chinese)

25. Habich-Sobiegalla, S. How do central control mechanisms impact local water governance in China? The case of Yunnan Province. China Q. 2018, 234, 444-462. [CrossRef]

26. Wan, Z.; Chen, J.H.; Sperling, D. Institutional barriers to the development of a comprehensive ballast-water management scheme in China: Perspective from a multi-stream policy model. Mar. Policy 2018, 91, 142-149. [CrossRef]

27. van den Brandeler, F.; Hordijk, M.; von Schonfeld, K.; Sydenstricker-Neto, J. Decentralization, participation and deliberation in water governance: A case study of the implications for Guarulhos, Brazil. Environ. Urban. 2014, 26, 489-504. [CrossRef]

28. Compagnucci, L.; Spigarelli, F. Fostering cross-sector collaboration to promote innovation in the water sector. Sustainability 2018, 10, 4154. [CrossRef]

29. Forster, J.J.; Downsborough, L.; Chomba, M.J. When policy hits practice: Structure, agency, and power in South African water governance. Soc. Nat. Resour. 2017, 30, 521-536. [CrossRef]

30. Xiao, X. River Chiefs System: An effective but not long-term mechanism. Environ. Educ. 2009, 5, 24-30. (In Chinese)

31. Daniell, K.A.; Coombes, P.J.; White, I. Politics of innovation in multi-level water governance systems. J. Hydrol. 2014, 519, 2415-2435. [CrossRef]

32. Moore, S.M. China's domestic hydropolitics: An assessment and implications for international transboundary dynamics. Int. J. Water Resour. Dev. 2018, 34, 732-746. [CrossRef]

33. Dai, L.P. A new perspective on water governance in China: Captain of the River. Water Int. 2015, 40, 87-99. [CrossRef]

34. Pia, A.E. Back on the water margin: The ethical fixes of sustainable water provisions in rural China. J. R. Anthropol. Inst. 2017, 23, 120-136. [CrossRef]

35. Wang, X.J.; Zhang, J.Y.; Yang, Z.F.; Shahid, S.; He, R.M.; Xia, X.H.; Liu, H.W. Historic water consumptions and future management strategies for Haihe River basin of Northern China. Mitig. Adapt. Strateg. Glob. Chang. 2015, 20, 371-387. [CrossRef]

36. Guo, Q.H.; Wu, J.J.; Xiao, L.S. Promoting ecosystem services through ecological planning in the Xianghe Segment of China's Grand Canal. Int. J. Sustain. Dev. World Ecol. 2016, 23, 365-371. [CrossRef]

37. Xua, G.H.; Xu, X.L.; Tang, W.B.; Liu, W.; Shi, J.; Liu, M.X.; Wang, K.L. Fighting against water crisis in China-A glimpse of water regime shift at county level. Environ. Sci. Policy 2016, 61, 33-41. [CrossRef]

38. Rogers, S.; Crow-Miller, B. The politics of water: A review of hydropolitical frameworks and their application in China. Wiley Interdiscip. Rev. Water 2017, 4, 1-10. [CrossRef]

39. Biba, S. China's 'old' and 'new' Mekong River politics: The Lancang-Mekong Cooperation from a comparative benefit-sharing perspective. Water Int. 2018, 43, 622-641. [CrossRef]

40. Boland, A. The trickle-down effect: Ideology and the development of premium water networks in China's cities. Int. J. Urban Reg. Res. 2007, 31, 21-40. [CrossRef]

41. Tang, K. River Chiefs System is not a simple responsibility. Water Resour. Prot. 2017, 5, 40-50. (In Chinese) 
42. Yang, X.; Griffiths, I.M. A comparison of the legal frameworks supporting water management in Europe and China. Water Sci. Technol. 2010, 61, 745-761. [CrossRef]

43. Ribot, J.; Agrawal, A.; Larson, A. Recentralizing while decentralizing: How national governments reappropriate forest resources. World Dev. 2006, 34, 1864-1886. [CrossRef]

44. Asad, G. Managing Water as an Economic Good Conference on Community Water Supply and Sanitation; World Bank: Washington, DC, USA, 1998.

45. Moore, S.M. The development of water markets in China: Progress, peril, and prospects. Water Policy 2015, 17, 253-267. [CrossRef]

46. Yang, X.L.; Xu, J.; Donzier, J.F.; Noel, C. A comparison of the water management systems in France and China. Front. Environ. Sci. Eng. 2013, 7, 721-734. [CrossRef]

47. Pohlner, H. Institutional change and the political economy of water megaprojects: China's south-north water transfer. Glob. Environ. Chang. Hum. Policy Dimens. 2016, 38, 205-216. [CrossRef]

48. Moore, S.M. Hydropolitics and inter-jurisdictional relationships in China: The pursuit of localized preferences in a centralized system. China Q. 2014, 219, 760-780. [CrossRef]

49. Thiel, A.; Egerton, C. Re-scaling of resource governance as institutional change: The case of water governance in Portugal. J. Environ. Plan. Manag. 2011, 54, 383-402. [CrossRef]

50. Andersson, I.; Petersson, M.; Jarsjö, J. Impact of the Water Framework Directive on local-level water management: Case study Oxunda Catchment, Sweden. Land Use Policy 2011, 29, 73-82. [CrossRef]

51. Borowski, I.; Le Bourhis, J.-P.; Pahl-Wostl, C.; Barraqué, B. Spatial misfit in participatory river basin management: Effects on social learning, a comparative analysis of German and French case studies. Ecol. Soc. 2008, 13, 7. [CrossRef]

52. Withanachchi, S.S.; Ghambashidze, G.; Kunchulia, I.; Urushadze, T.; Ploeger, A. A Paradigm Shift in Water Quality Governance in a Transitional Context: A Critical Study about the Empowerment of Local Governance in Georgia. Water 2018, 10, 98. [CrossRef]

53. Zhang, Y.; Zhang, B.; Bi, J. Policy conflict and the feasibility of water pollution trading programs in the Tai Lake Basin, China. Environ. Plan C 2012, 30, 416-428. [CrossRef]

54. Scott, D. The great power 'Great Game' between India and China: 'The logic of geography'. Geopolitics 2008, 13, 1-26. [CrossRef]

55. Finlayson, B.L.; Barnett, J.; Wei, T.; Webber, M.; Li, M.; Wang, M.Y.; Chen, J.; Xu, H.; Chen, Z. The drivers of risk to water security in Shanghai. Reg. Environ. Chang. 2013, 13, 329-340. [CrossRef]

56. Crow-Miller, B. Discourses of deflection: The politics of framing China's South-North Water Transfer Project. Water Altern. Interdiscip. J. Water Politics Dev. 2015, 8, 173-192.

57. Ge, J.H.; Resurreccion, B.P.; Elmhirst, R. Return migration and the reiteration of gender norms in water management politics: Insights from a Chinese village. Geoforum 2011, 42, 133-142. [CrossRef]

58. Prudhomme, R. The dangers of decentralization. World Bank Res. Obs. 1995, 10, 201-220. [CrossRef]

59. Capodaglio, A.G.; Callegari, A. Can payment for ecosystem services schemes be an alternative solution to achieve sustainable environmental development? A critical comparison of implementation between Europe and China. Resources 2018, 7, 40. [CrossRef]

(C) 2019 by the authors. Licensee MDPI, Basel, Switzerland. This article is an open access article distributed under the terms and conditions of the Creative Commons Attribution (CC BY) license (http://creativecommons.org/licenses/by/4.0/). 